\title{
The cultural attitudes of nurses and the analysis of the interactive relation between the nurse and the patient
}

\author{
목ife Özen ${ }^{1}$, @Selma Kahraman ${ }^{2}$ \\ ${ }^{1}$ Eyyübiye Training and Research Hospital, Şanlıurfa, Turkey \\ ${ }^{2}$ Harran University, Health Sciences Faculty, Public Health Nursing, Şanlıurfa, Turkey
}

Cite this article as: Özen A, Kahraman S. The cultural attitudes of nurses and the analysis of the interactive relation between the nurse and the patient. J Health Sci Med 2021; 4(1): 84-90.

\begin{abstract}
Aim: This study was aim to determine the effects of nurses' cultural approach on the patient care, to reveal the relation between the nurse and the patient, and to determine the factors that affect this relation.

Material and Method: A cross-sectional descriptive study was conducted in a hospital. 300 nurses participated in the study. Multicultural Attitude Scale and Care Oriented Nurse-Patient Interaction Scale were used to obtain data that was collected between March 2016 and June 2016. Descriptive statistics and independence t-test corelation were used to analyse the data.

Result: The attitudes and behaviors of the nurses concerning care oriented nurse-patient interaction are positive (significance is $297.4 \pm 56.9$, sufficiency is $284.8 \pm 60.7$, and practicality is $281.3 \pm 70.7$ ); however, it was found that the cultural attitudes of the nurses were not positive. The relation between total sufficiency and practicality points of curing oriented nurse-patient interaction scale and multiculturalism attitude scale were evaluated as positive and medium level ( $\mathrm{r}: 0.248, \mathrm{p}<0.05, \mathrm{r}: 0.302$, $\mathrm{p}<0.05)$

Conclusions: This study creates a resource for an education plan on developing cultural awareness among nurses. To increase the quality of patient and individual patient care, the cultural attitudes of nurses should be improved.

Keywords: Nursing, culture, attitudes, care, health
\end{abstract}

\section{INTRODUCTION}

The removal of borders, increase in migration rate, traveling becoming easy and common, and increase in dialogues among people from different backgrounds led to coexistence with people from different cultures. Thus, the societies turned into multicultural structures. This result increased the importance of transcultural nursing. Transcultural nursing is a field of study that deals with the differences and similarities of people's cultures, gathers information by focusing on the cultural beliefs and standart of judgements, and uses these knowledge in determining convenient ways for providing nursing care (1-4). Social and cultural differences and intolerance against cultural differences cause an increase in the cost of the care, poor people not benefiting from the health care, gender apartheid, inequalities, cultural conflicts, and racism. Moreover, when the healthcare personnel are not familiar with the culture of the individuals that they give care service, when there is a cultural differences between the nurse and the

patient, or when the nurse uses complex technology, it causes fear, resistance, impatience, and disappointment towards the nurse. For this reason, patients' and nurse's self confidence can only be increased and high-quality nursing care can only be provided by transcultural nursing (2,5-7).

Giving culturally susceptible nursing service is vocationally multidimensional. Knowing and understanding the culture of the patient and having cultural awareness are very important when giving care by the nurse $(8,9)$. Cultural awareness is exploring one's own cultural background and making self-assessment. Previous studies were conducted on the approach of the individuals from different cultures and these studies put forth the cultural structures of patients $(4,7,9-11)$. However, there are no studies on how the cultural attitudes affect the relation between the patient and the nurse or on the factors that affect this relation. 


\section{Background}

People have the ability of developing solutions by using cultural means when they comply with their environment. The understanding of the cultural dimension is achieved by the field of "anthropology". Anthropology describes human and culture from the point of a holistic (integrative) view. For this reason, the cultural basis of human behaviors has great importance for the nursing practices. All the aspects of culture are effective in nursing practices. One of the most important functions of nursing is care. Human caring is seen as the origin and essence of nursing $(2,3)$. Giving care is the center of nursing knowledge and practices and involves helping, supportive, and facilitator roles for the individual or the group to meet present or expected needs. Caring of nurse is an interactive and interpersonal process occurring in moments of caring between nurse and patient (12). Leininger stated that care is basic for the health of the individual and is the most important dimension that distinguishes nursing from other disciplines. Consequently, there can be no cure without care, while there is caring without cure (12). Comparative studies show that professional nursing care gathers in itself the scientific and humanistic helping types for the continuation of the conditions needed to continue living at the desired level. Therefore, to be able to give good care, a professional nurse should know the importance and meaning of physical, psychological, cultural, and social values of the individual or a group $(2,13,14)$.

\section{Aim of the Study}

This syudy aimed to determine the relation between the nurse and the patient and the cultural attitudes of the nurses, to provide awareness about the subject, to make the care based upon culture irreplaceable, and to create a resource for the future studies that will focus on the subject matter. However, to the best of our knowledge, there is no studies dealing with the effects of nurses' own cultures on the patient care. This study proves that why transcultural nursing is irreplaceable. When the literature is reviewed, it is seen that there are studies focusing on preparing, practicing, and evaluating the patient care plans according to the cultures of patients. Green and Davis (14) showed a positive correlation between patient perceptions of nurse caring behaviours and patient satisfaction. Wolf, Miller and Hajynezhad and their colleagues $(12,13)$ also showed a significant correlation between patient reports of nurse caring and their satisfaction with nurse curing. Knowledge, attitude and skills of nurses are the three most important factors in evaluating the quality of nursing care behaviors. In this context, the following hypotheses were tested:
Hypothesis 1. As the attitudes of the nurses that are based upon culture are increased, the interaction between the nurse and the patient will be at higher quality.

Hypothesis 2. The cultural attitudes of the nurses are affected by their socio- demographic characteristics.

Hypothesis 3. Care oriented nurse- patient interaction is affected by nurses' socio- demographic characteristics.

\section{MATERIAL AND METHOD}

\section{Design}

This study is a cross-sectional descriptive research.

\section{The Period of the Study}

This study was carried out between March and June 2016 and was designed as a cross-sectional descriptive research. The population and sample of the study involves 1137 nurses working at hospitals and primary care clinics in a city in the southeastern Anatolia region, Turkey. The research sample size is calculated with $\alpha=0.05$ significance level and with $d=0.05$ sampling error at $\mathrm{p}=0.5, \mathrm{q}=0.5$ column as minimum 278 people (16). To represent the population, the minimum sample size is increased to 300 . The nurses in the sampling group were selected by using stratified sampling method.

\section{Study Setting}

First of all, the aim of the study was explained to the nurses and the points to consider during filling in the survey were indicated. This session lasted for 15-20 minutes. The survey was filled in by the nurses who accepted to participate in the study and who were working during working hours (from 08 am to $4 \mathrm{pm}$ ) under researcher's supervision.

\section{Data Collection Tools}

Individual Data Collection Form was used for the socio-demographic characteristics of the nurses, Multicultural Attitude Scale was used to determine the cultural approach of the nurses, and Care-Oriented Nurse-Patient Interactive Relation Scale was used to determine the interactive relation of the patient-nurse.

\section{Individual Data Collection Form}

The Individual Data Collection Form was prepared by the researchers, that composed of 8 questions about socio-demographic characteristics and 7 questions about the nursing profession.

\section{Multicultural Attitude Scale (MAS)}

Multiculturalism attitude scale was first developed by Munreo and Perseon (2006) and improved based upon the components made up of multicultural approach of Banks (2007). The attitude scale has 5 dimensions. It is composed of 5 dimensions as flexibility, social 
enterprise, empathy, emotional stability, and explicitness. Likert type collection tool was scaled between "(1) strongly disagree to (5) my thoughts exactly". At the end of the study, the Alpha Reliability Coefficient of the confidence test was found as 0.65. As the points increase, it was inferred as the attitudes based upon cultures of nurses were increased.

\section{Care-Oriented Nurse-Patient Interactive Relation Scale (CONPIRS)}

This scale was developed by Cossette, Caraa, Ricarda, and Pepin (2005) to evaluate the attitudes and behaviorsof the nurses related to care which is based upon Watson's Care Hypothesis. The scale was adapted to Turkish by Atar and Aștı (2012). The scale is composed of 3 dimensions (significance, sufficiency, and practicality), 10 subscales (humanism, hope, susceptibility, contributing to the relation, expressing the emotions, problem solving, education, environment, requirement, and spirituality) and 70 articles. Atar and Aștı (2012) found the Cronbach Alpha Reliability Coefficient is $\mathrm{A}=0.99$ for significance dimension, $\alpha=0.98$ for sufficiency dimension, and $\alpha=0.99$ for practicality dimension. The minimum point was find 70 and maksimum point was find 350 from Likert type CONPIRS that is composed of 70 articles. The statements in the Likert type with five articles are scaled from Strongly Disagree (1), Disagree (2), Neutral (3), Agree (4), and Strongly Agree (5). It is evaluated that as the score taken from CONPIRS increases, the attitudes and behaviors of the nurses about care oriented nurse-patient interaction are affected positively. Cronbach's Alpha Reliability Coefficient of the scale in this study was found for significance, sufficiency, and practicality dimensions respectively $0.94,0.96,0.98$.

\section{RESULT}

Sixty percent of the nurses are older than 25 , the youngest is 19 years old while the oldest is 54 years old. The $73.0 \%$ of the nurses are women. The $44.3 \%$ of them are single and 37.5 of them are from Şanlıurfa. The $55.7 \%$ of them are Turkish origin and $36.0 \%$ are Kurdish. $74.3 \%$ of the nurses' native language is Turkish. $56.5 \%$ of the nurses have been working as a nurse from one to five years. $64.2 \%$ of them indicated that they have chosen this profession willingly. $93.0 \%$ of them told that they have knowledge about cultural differences.

According to Table 1, when the total average points of care oriented nurse- patient interaction scale is evaluated, the average of total points for significance, sufficiency, practicality are 297.4 $\pm 56.9,284.8 \pm 60.7$, $281.3 \pm 70.7$ respectively. The data show that the attitudes and behaviors related to care-oriented nurse-patient interaction are positive.

According to the results of humanism, subdimension of care oriented nurse-patient interaction scale, average point of significance is determined as $25.7 \pm 4.3$; average point of sufficiency is $24.5 \pm 4.5$; and average point of practicality is $23.3 \pm 5.0$. Therefore, it is determined that the manners and behaviors of the nurses relating to humanism are positive.

For hope subdimension, the average point of significance is determined as $30.0 \pm 5.5$, the average point of sufficiency is determined as 28.6 \pm 6.0 , and the average point of practicality is determined as $28.6 \pm 5.3$. According to the average points of subdimension hope, it is determined that the manners and behaviors of the nurses relating to hope are positive.

For susceptibility subdimension, the average point of significance is determined as $24.9 \pm 4.6$, the average point of sufficiency is determined as $19.3 \pm 4.6$, and the average point of practicality is determined as $24.0 \pm 5.7$. According to average points of subdimension susceptibility, it is determined that the attitudes and behaviors of the nurses relating to susceptibility are positive for significance and practicality but not for sufficiency.

\begin{tabular}{|c|c|c|c|c|c|c|}
\hline \multirow{2}{*}{$\begin{array}{l}\text { Scale and the sub dimensions } \\
\text { Subdimensions }\end{array}$} & \multicolumn{2}{|c|}{ Momentousness } & \multicolumn{2}{|c|}{ Sufficiency } & \multicolumn{2}{|c|}{ Workableness } \\
\hline & Min-Max & $\mathrm{X} \pm \mathrm{SS}$ & Min-Max & $\mathrm{X} \pm \mathrm{SS}$ & Min-Max & $\mathrm{X} \pm \mathrm{SS}$ \\
\hline 1:Humanism & $6-30$ & $25.7 \pm 4.3$ & $6-30$ & $24.5 \pm 4.5$ & $6-30$ & $23.3 \pm 5.0$ \\
\hline 2: Hope & $7-35$ & $30.0 \pm 5.5$ & $7-35$ & $28.6 \pm 6.0$ & $7-35$ & $28.6 \pm 5.3$ \\
\hline 3: Susceptibility & $6-30$ & $24.9 \pm 4.6$ & $6-30$ & $19.3 \pm 4.6$ & $6-30$ & $24.0 \pm 5.7$ \\
\hline 4: Contributing relation & $7-35$ & $30.0 \pm 5.1$ & $7-35$ & $28.3 \pm 5.4$ & $7-35$ & $29.0 \pm 6.6$ \\
\hline 5: Expressing the emotions & $6-30$ & $25.4 \pm 6.2$ & $6-30$ & $23.5 \pm 6.5$ & $6-30$ & $24.3 \pm 5.2$ \\
\hline 6: Problem solving & $6-30$ & $24.8 \pm 4.8$ & $6-30$ & $23.4 \pm 6.0$ & $6-30$ & $23.7 \pm 6.5$ \\
\hline 7: Education & $9-45$ & $38.2 \pm 7.0$ & $9-45$ & $37.1 \pm 8.3$ & $9-45$ & $35.3 \pm 7.2$ \\
\hline 8: Environment & $7-35$ & $29.6 \pm 5.1$ & $7-35$ & $28.8 \pm 5.5$ & $7-35$ & $28.3 \pm 7.3$ \\
\hline 9: Requirement & $10-50$ & $43.4 \pm 7.9$ & $10-50$ & $41.6 \pm 8.6$ & $10-50$ & $41.1 \pm 8.9$ \\
\hline 10: Spirituality & $6-30$ & $25.4 \pm 6.4$ & $6-30$ & $24.3 \pm 5.3$ & $6-30$ & $23.7 \pm 6.5$ \\
\hline TOTAL & $70-350$ & $297.4 \pm 56.9$ & $70-350$ & $284.8 \pm 60.7$ & $70-350$ & $281.3 \pm 70.7$ \\
\hline
\end{tabular}


According to Table 2, it isdetermined that the nurses have taken $21.6 \pm 3.5$ points from the social enterprise that is the subdimension of multicultural attitude scale and this means that the attitudes of the nurses according to social enterprise are good. It is also determined that the nurses have taken $24.0 \pm 6.6$ points from emphaty that is the subdimension of multicultural attitude scale and this means that the attitudes of the nurses according to social enterprise are low. The average points for the subdimension of emotional stability of the nurses are 25.6 \pm 5.6 and this average point is low. The average points for the subdimension of explicitness of the nurses are $19.0 \pm 3.6$ and the average points for the subdimension of flexibility of the nurses is $13.5 \pm 2.1$. According to these average points, it is determined that the attitudes of the nurses for both explicitness and flexibility are good. When the total points of multicultural attitude scale are evaluated, the nurses have taken $82.3 \pm 7.5$ points and this average point shows us that the attitudes of the nurses are low.

Tablo 2. The average points that the nurses take from total points and points taken from subdimensions of multicultural attitude scale

\begin{tabular}{|llcc|}
$\begin{array}{l}\text { Multicultural } \\
\text { attitude scale }\end{array}$ & The number of the title & Max-Min & $\mathbf{X} \pm \mathbf{S S}$ \\
\hline & 1: Social enterprise & $8-30$ & $21.6 \pm 3.5$ \\
& 2: Empathy & $14-60$ & $24.0 \pm 6.6$ \\
\cline { 2 - 2 } Subdimensions & 3: Emotional stability & $7-68$ & $25.6 \pm 5.6$ \\
\cline { 2 - 4 } & 4: Explicitness & $5-25$ & $19.0 \pm 3.6$ \\
& 5: Flexibility & $7-19$ & $13.5 \pm 2.1$ \\
& Total & $63-126$ & $82.3 \pm 7.8$ \\
\hline
\end{tabular}

The correlation between the average points of care oriented nurse-patient interaction scale and multicultural attitude scale are given in Table 3. There are no significant relations between the sufficiency points of care oriented nurse-patient interaction scale and total points of multiculturalism attitude scale $(\mathrm{r}$ : $0.100 ; p>0.05)$. However, there are is a positive relation between the sufficiency and practicality points of care oriented nurse-patient interaction scale and total points of multicultural attitude scale ( $\mathrm{r}: 0.248, \mathrm{p}<0.05 ; \mathrm{r}: 0.302$, $\mathrm{p}<0.05)$.
The socio-demographic characteristics of the nurses are themale nurses have taken $295.1 \pm 49.2$ for average points of momentousness from CONPIRS and 278.0 \pm 45.0 for sufficiency and $287.9 \pm 44.5$ for workableness. These values are respectly $298.8 \pm 40.4,280.0 \pm 43.7$ and $286.8 \pm 47.4$ for female nurses. When the statistical differences are evaluated, there aren't meaningfull difference between the three values of the two sexualities $(p>0.05)$. When the relation between the culture and sexualities is evaluated the male nurses have taken lower points from female nurses and as a result it's determined that the manners of male nurses related to culture is negative $(\mathrm{p}>0.05)$. When the relation between the age and the scale are evaluated, the nurses aged 25 and lower are taken more points for sufficiency and workableness except momentousness at CONPIRS and as a result the manners of this aged nurses are determined as positive. But the statistical difference for all is not meaningful( $p>0.05)$. At the study the question; "nurses should have cultural knowledge" is answered as yes or no by the nurses. It's determined that the average points of all the answers by nurses for this question are the same $(\mathrm{p}>0.05)$.

\section{DISCUSSION}

The health necessities of individuals are different according to cultural structures (1). The worthy of notice during the patient care with cultural approach is to find an answer to the question: "Is this group culturally different from my cultural group and how much is the dimension of this difference?" In this study, which explores the relation between the nurse and the patient, it isevaluated that there is a mean relation between the sufficiency and practicality total points of CONPIRS and MAS (Table 3, $\mathrm{p}<0.05$ ). As the attitudes of the nurses based upon their culture increase, the attitudes and behaviours during patient/ individual care are also affected positively (Hypothesis 1).

As the cultural awareness level of the personnel increases, the sufficiency during patient care also increases. In one study, the patients evaluated the behaviours of the nurses e.g. saying "how are you today?", sharing time with them, being there for them, communicating with them,being willing to help them, caring about them and the patients indicated that they feel happy for that (2).

Tablo 3. The correlation between care oriented nurse-patient interaction scale and multicultural attitude scale

\begin{tabular}{|c|c|c|c|c|c|c|c|c|c|c|c|c|}
\hline \multirow[t]{2}{*}{$\begin{array}{l}\text { Care orianted nurse patient } \\
\text { scale total points }\end{array}$} & \multicolumn{2}{|c|}{$\begin{array}{c}\text { Multiculturalism attitude } \\
\text { scale total points }\end{array}$} & \multicolumn{2}{|c|}{$\begin{array}{c}\text { Social } \\
\text { enterprise }\end{array}$} & \multicolumn{2}{|c|}{ Empathy } & \multicolumn{2}{|c|}{$\begin{array}{c}\text { Emotional } \\
\text { stability }\end{array}$} & \multicolumn{2}{|c|}{ Explicitness } & \multicolumn{2}{|c|}{ Flexibility } \\
\hline & $\mathbf{r}$ & $\mathbf{p}$ & $\mathbf{r}$ & $\mathbf{p}$ & $\mathbf{r}$ & $\mathbf{p}$ & $\mathbf{r}$ & $\mathbf{p}$ & $\mathbf{r}$ & $\mathbf{p}$ & $\mathbf{r}$ & $\mathbf{p}$ \\
\hline Momentousness & 0.100 & 0.86 & 0.320 & 0.00 & -0.150 & 0.009 & 0.777 & 0.000 & 0.664 & 0.00 & 0.584 & 0.00 \\
\hline Sufficiency & 0.248 & 0.00 & 0.348 & 0.00 & -0.354 & 0.00 & 0.312 & 0.00 & 0.306 & 0.00 & 0.233 & 0.00 \\
\hline Workableness & 0.302 & 0.00 & 0.348 & 0.00 & 0.327 & 0.00 & 0.330 & 0.00 & 0.312 & 0.00 & 0.291 & 0.00 \\
\hline
\end{tabular}


In a more recent study, it is indicated that the hardest requirements to meet between the nurse and the patient are the necessities based upon cultural differences (11). In another study, nurses indicated that they have problems because of language differences $(76 \%)$, dialect differences (4.6\%), and privacy issues (40.4\%) (17).

In studies that were conducted by collating the care service given by the nurses and the requirements for the patients, it is reported that the patients want nurses to talk to them, to let them talk and tell their feelings, to listen to them, to try to understand them, to worry about them, to inform them, to be reachable, and to be facilitative. The patients indicate that these expectations are not met. In addition, supporting these studies, in our study, the average points of empathy and emotional stability that are the subdimensions of multiculturalattitude scale are low (Table 2).

It may be expected that growing cultural differences between the nurse and the patient affect the care provided and the nurses cannot fulfill the requirements. The patients can easily communicate with the nurses who understand the culture of the patient, who can communicate with the patient with simple words, and who knows both his/her own culture and the patients' culture and do not deny them. However, it is disappointing to see that there is an average relation between the understanding the culture and the care nurses give in this study. That is why it isimportant to increase the number of trainings about servicing based upon cultural awareness to improve the quality of the care provided (Hypothesis 1).

Although $93.0 \%$ of the nurses told that they know about cultural awareness from books and school, it is found out that their cultural attitudes are low (Table 2). In the study by Aktaş et al. when the knowledge levels of the nurses about transcultural nursing are evaluated, it is seen that $26.9 \%$ of them do not have any knowledge at all about the subject. The nurses described transcultural as "gathering of different cultures" and transcultural nursing as "servicing patients from different cultures"(11). On the contrary to the findings of our study, Leung and Bond determined that $65 \%$ of the students of nursing know the term of transcultural nursing (18). The findings may show that nurses are not culturally sensitive enough. Culturally insensitive nurses may perform wrong applications or may disservice the patient. Not giving beneficial care to the patients from different cultures and giving wrong messages e.g. some cultures are less important than others show the healthcare personnel's insufficiency about cultural awareness. These findings show us that the transcultural nursing is not emphasized enough in education programs in our country. When the average points of care and culture scale are evaluated, the nurses who have cultural knowledge and who do not took nearly the same points (Table 4, $p>0.05$ ). This result makes us think that the nurses do not have sufficient cultural knowledge.

The attitudes and behaviors related to care-oriented nurse-patient interaction are determined as positive (Table 1). In a study, nursing is defined as "an interpersonal interaction process". Nursing may be defined as a science and art of giving care and care may be defined as an interpersonal process (19). Individuals from different cultural characteristics affected from beliefs and traditions when perceiving health and illness. The cultural values, beliefs, and approaches affect how the patients benefit from the nurse care (20). As indicated in the literature, health care professionals should use their problem-solving skills to help the individuals, increase the quality of the care, and to satisfy the patients. To give sufficient health care to individuals, to family, and to the society, nurses should have knowledge about underlying cultural characteristics about health and illness. When the nurses interract with the individuals, they should make the evaluation culturally sensitive. This evaluation may be indept and may provide a basis for future evaluations. People who are looking at communication from a cultural point of view may distinguish differences between cultures, try to give correct messages, and try to make contribution for efficient communication between members of different cultures (20-22).

It is evaluated that $73.0 \%$ of the nurses participating in the study are women. Nursing is not only a woman occupation anymore both in our country and in the world and there are increasing tendencies and ambitions supporting this aim. Thus, the number of male nurses is increasing day by day. The number of male students of nursing increased as the number of male students were only 27 in 2006-2007 academic year while it reached to 14.929 in $2015(23,24)$.

According to gender of the nurses, the total points of multiculturalism attitude scale of male nurses are lower than of female nurses ( $p>0.05$, Hypothesis 2). In the study of Çelik et al. (2012) (25), the patients who have not been given care by male nurses before think that nursing is a woman occupation and that males should not be nurses. In addition, they do not want to be given service by a male nurse and think that both she and her relatives would be annoyed because of it. Besides, the patient thinks that she would have difficulty to tell her problem and that male nurses should give service to male patients. Similarly, the patients who have not been given care by male nurses stated that they are indecisive about male nurses' providing good care or not, about changing the negative thoughts about nursing, about male nurses' being as polite and tolerant as female nurses or not (27). When the care oriented nurse-patient interaction scale is evaluated, it is seen that the male nurses have lower 
average points than female nurses do on significance and sufficiency and that male nurses have higher points on practicality ( $\mathrm{p}>0.05$, Hypothesis 3 ).In the study by Ünver et al (26), the female students of nursing department thought that the female patients would be shy while the male students of nursing department thought that they would not be shy before the clinical practice. After the clinical practice, all the female students reported that the female patients were not shy during the applications while the male students stated that the female patients were acting shy during the applications (28). In opposite, in the study by Potur and Bilgin (2014) (27), the male students of nursing department stated that when the patients discriminate,it makes them stressful and that when the patient is female and makes sexual discrimination, they feel stressed. Although the male nursing students thought that they may be discriminated, there were not too much adverse events during clinical practices. After clinical practices, the male nursing students determined to work at clinics of obstetrics and gynecology.

Among the nurses who participated in the study, $60.0 \%$ of the nurses are older than 25 , the youngest of the nurses is 19 years old and the oldest is 54 years old. In CONPIRS, it is determined that, according to sufficiency and practicality, the age is a positive variable for the nurses aged under 25 ( $p>0.05)$. The same is seen in MAS. The cultural aproach of the nurses under 25 is positive $(\mathrm{p}>0.05)$. These results indicate that the nurses of under age 25 believe that the care-oriented nursing and patient interaction is important and they find themselves sufficient and practical. In the study by Kostak et al. (2010), most of the nurses stated that they do not provide moral care (28). Similar to the findings of our study, in the study by Aktaş et al., as the average age and the number of years of experience of the nurses increase, the thought of "giving health care apppropriate to culture" decreases (11). In the study by Eğlence and Şimşek, there are no statistically significant differences among the age of the nurses, their education level, and the number of years of experience (29). In another study, the statistical difference among the average of ages of nurses, their marital status, field experience, and the average of moral points are not significant (30). The main reasons for not fullfilling the care requirement may be the lack of time, the working environment, lack of personnel, lack of knowledge, or lack of opportunities. The reasons for the differences among the studies might stem from the differences in the qualities of the hospitals and the characteristics of the nurses.

Restrictions: The questionnaire form used in this study was too long that damages the credibility of the answers. Conducting observations with an in-dept analysis will increase the validity of the results.

\section{CONCLUSION}

The most important result obtained from this study is the interaction between the nurse and the patient: even though their attitudes and behaviors are positive, their cultural approaches are not sufficient enough. Another significant result of the study is about the effect of cultural approaches of the nurses to patient's care. The effect of the cultural approach of nurses to patient's care is positive or average that is unsettling. Therefore, precautions should be taken to prevent it both during the education of nurses and during in-service trainings. To increase the quality of the patient/individual care, the cultural attitude of the nurses should be improved. This article forms a basis to improve cultural awareness and to revise education plans based upon improving cultural awareness.

What is already known about this topic?

-Giving culturally-susceptible nursing service is vocationally multidimensional.

-Knowing and understanding the culture of the patient and having cultural awareness are very important when giving care by the nurse

-Previous studies were conducted on the approach of the individuals from different cultures and these studies put forth the cultural structures of patients.

-When the literature is reviewed, it is seen that there are studies focusing on preparing, practicing, and evaluating the patient care plans according to the cultures of patients.

\section{What this paper adds?}

-This Study explained how the cultural attitudes affect the relation between the patient and the nurse or on the factors that affect this relation.

-This study proves why transcultural nursing is irreplaceable.

-With this study, it isaimed to determine the relation between the nurse and the patient and the cultural attitudes of the nurses, to provide awareness about the subject, to make the care based upon culture irreplaceable, and to create a resource for the future studies that will focus on the subject matter.

\section{The implications of this paper:}

- To increase the quality of patient/ individual care, the cultural attitudes of nurses should be improved.

-This study creates a resource for an education plan on developing cultural awareness among nurses.

\section{The Evaluation of the Data}

Statistical Package Social Sciences (SPSS) 16.0 program was used to evaluate the data. For the evaluation, numerical percentage distribution, average, and standart deviation data were used in the computer program. The data analysis for the three dimensions of sociodemographic characteristics scale was calculated by the 
independence t-test and corelation. Moreoever, normal distributional corelation between total point averages of all the subscales of them is evaluated by Shapiro- Wilk test.

\section{ETHICAL DECLARATIONS}

Ethics Committee Approval: For applicability of the study, a writen permission was obtained (25/02/2016, Session 01 and no. 74059997.050.04/23) from University Medical Faculty Ethics Committee

Informed Consent: The study was the consent of the nurses who accepted to participate in the study was taken.

Referee Evaluation Process: Externally peer-reviewed. Conflict of Interest Statement: The authors have no conflicts of interest to declare.

Financial Disclosure: The authors declared that this study has received no financial support. Author Contributions: All of the authors declare that they have all participated in the design, execution, and analysis of the paper, and that they have approved the final version.

\section{REFERENCES}

1. Prosen M. Introducing transcultural nursing education: Implementation of transcultural nursing in the postgraduate nursing curriculum. Procedia Soc Behav Sci 2015; 174: 149-55.

2. Stevenson N. Developing cultural understanding through storytelling. JTTT 2019; 19: 8-21.

3. Leininger M. Cultural care theory: A major contribution to advance transcultural nursing knowledge and practices. J Transcult Nurs 2002; 13: 189-92.

4. Bekar M. Kültürlerarası (transkültürel) hemsirelik. Toplum ve Hekim Derg 2001; 16, 136-41.

5. Temel A. Çok kültürlülük ve kültürlerarası iletișimin sağlık hizmetlerinin sunumuna etkileri. (Edit), Esen E, Yazıcı Z. Onlar bizim hem şehrimiz uluslararası göç ve hizmetlerin kültürlerarası açılımı. Erek Ofset Matbaacılık, 2011; Ankara, 48.

6. Özcan A. İletişim Uluslararası Kültür. (Edit). Seviğ E, Tanrıverdi G. Intercultural Nursing. Kayhan Yayıncilık. 1. Basin 2014 İstanbul, 86 .

7. Jones ME, Cason CL, Bond ML. Cultural attitudes, knowledge, and skills of a health workforce. J Transcult Nurs 2004; 15: 283-90.

8. Atkins M, Stone KS. Undergraduate and graduate students partnering in a short-term transcultural experience in Honduras. ABNF Journal 2006; 17: 147-51.

9. Başalaniz F, Bayık T. Hemşirelikte Kültürel Yeterlik. Aile ve Toplum 2009; 11: 17.

10. Tanrıverdi G, Seviğ Ü, Bayat M, Birkök MC. Hemşirelik bakımında kültürel özellikleri tanılama rehberi. J Hum Sci 2009; 6: 793-806.

11. Aktaş YY, Uğur HG, Orak SO. Hemşirelerin kültürlerarasi hemşirelik bakimina ilişkin görüşlerinin incelenmesi. UHD 2016; 8: $120-35$.

12. Hajinezhad ME, Azodi P. Nurse caring behaviors from patients' and nurses' perspective: European Online. J Nat Soc Sci 2014; 3: 1010-7.

13. Ünsal A. Türk kültüründe geleneksel hasta bakımı: Anadolu örneği. Y.Y.Ü. Sosyal Bilimler Enstitüsü Derg Special Edition 2017; 2: 1-12.
14. Green A, Davis S. Toward a predictive model of patient satisfaction with nurse practitioner care. J Am Acad Nurse Pract 2005; 17: 139-48.

15. Wolf ZR, Miller PA, Devine M. Relationship between nurse caring and patient satisfaction in patients undergoing invasive cardiac procedures. Med Surg Nurs 2003; 12: 391-6.

16. Yazıcıoğlu Y, Erdoğan S. SPSS uygulamalı bilimsel araştırma yöntemleri. Detay Yayıncılık, 2004; Ankara, 50.

17. Ayaz S, Bilgilı N, Akın B. The transcultural nursing concept: a study of nursing students in Turkey. Int Nurs Rev 2010; 57: 44953.

18. Leung K, Bond MH. Social axioms: A model for social beliefs in multi-cultural perspective. Adv Exp Soc Psychol 2004; 36: 119-97.

19. Kumcağız H, Yılmaz M, Balcı ÇS, Aydın Aİ. Hemşirelerin iletişim becerileri: Samsun ili örneği. Dicle Tip Derg 2011; 38: 49-56.

20. Yalçın N, Aştı T. Hemşire-hasta etkileşimi. İstanbul Üniversitesi FNJN 2011; 19: 54-9.

21. Kelleci M, Gölbaşı Z, Doğan S, Tuğut N. Entegre eğitim programında öğrenim gören hemşirelik öğrencilerinin problem çözme becerileri: Bir izlem çalışması. İstanbul Üniversitesi FNJN 2011; 19: 23-8.

22.Halk Sağlığı Kurumu. Sağlık araştırmaları ve sağlık hizmet sunumunda kültürel yaklaşım 2016; Ankara.

23.Şahin NH, Bayram GO, Avcı D. Kültürlere duyarlı yaklaşım: transkültürel hemşirelik. HEAD 2009; 6: 2-7.

24. Dinç L. Bakım kavramı ve ahlaki boyutu. HÜSBFD 2010; 74-82.

25. Çelik AS, Pasinlioğlu T, Çilek M, Çelebi A. Kadın doğum servislerinde yatan hastaların erkek hemşireler hakkındaki düșüncelerinin belirlemesi. Ana Hemş Sağ Bil Derg 2012; 5: 25461.

26. Ünver S, Avcıbaşı İM, Özkan ZK, Motör D. Hemşirelik bölümünde okuyan erkek öğrencilerin sosyal çevrelerinde yaşadıkları sorunlar. ITOBIAD 2016; 5: 1636-48.

27. Potur DC, Bilgin NÇ. Assessment of clinical stress in male and female nursing students, as measured on the first and last day of the obstetrical nursing clinic course. KASHED 2014; 1: 93-106.

28. Kostak MA, Çelikkalp Ü, Demir M. Hemşire ve ebelerin maneviyat ve manevi bakıma ilişkin düşünceleri. MÜ Hem. Bilim ve Sanatı Derg Sempozyum Özel Sayısı 2010; 218-25.

29. Eğlence R, Şimşek N. Hemşirelerin maneviyat ve manevi bakım hakkındaki bilgilerinin değerlendirilmesi. ACU Sağlık Bil Derg 2014; 5: 48-53.

30.Özbaşaran F, Ergül Ş, Bayık TA, Gürol AG, Çoban A. Turkish nurses' perceptions of spirituality and spiritual care. J Clin Nurs 2011; 20: 3102-10. 